\title{
Evaluation of In Vitro Activity of Ceftolozane-tazobactam and Ceftazidime-avibactam Against Carbapenemase-producing Multi-drug Resistant Klebsiella pneumoniae Isolates
}

Karbapenemaz Üreten Çoklu Illaca Dirençli Klebsiella pneumoniae Izolatlarında SeftolozanTazobaktam ve Seftazidim-Avibaktamın Etkinliğinin Değerlendirilmesi

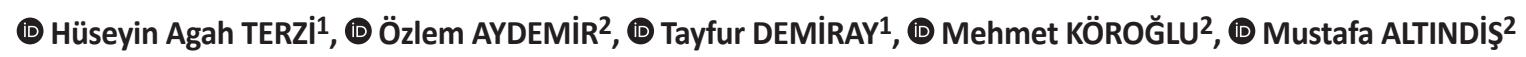 \\ 1Sakarya University Training and Research Hospital, Medical Microbiology Laboratory, Sakarya, Turkey \\ 2Sakarya University Faculty of Medicine, Medical Microbiology Laboratory, Sakarya, Turkey
}

\section{Abstract}

Introduction: This study aims to assess the in vitro activity of ceftazidime-avibactam (CZA) and ceftolozane-tazobactam (C/T) against the multidrug resistant (MDR) Klebsiella pneumoniae. Furthermore, we aimed to determine the types of carbapenemase enzyme responsible for carbapenem resistance and compare the activity of ceftolozane-tazobactam and CZA according to the types of carbapenemase enzymes produced.

Materials and Methods: Twenty-two MDR isolates were investigated in the study. The identification and antimicrobial susceptibilities of the isolates were performed by VITEK 2 (BioMérieux, France) automated system. The activity of C/T and CZA was determined by the gradient strip test (Liofilchem MIC strip test, Italy). In all $K$. pneumoniae isolates, bla $\left.\right|_{I M P-1}, b / a_{K P C^{\prime}} b / a_{N D M-1}, b / a_{O X A-48}$ and $b / a_{V I M}$ gene regions encoding the carbapenemase enzyme were investigated by using Xpert CARBA-R test kits (Cepheid, Sunnyvale, CA, USA) of the Gene-Xpert ${ }^{\oplus}$ system.

Results: Ceftolozane-tazobactam resistance was detected in 21 (95\%) isolates, whereas CZA resistance was detected in six (27\%) isolates. Among the $22 \mathrm{~K}$. pneumoniae isolates, NDM-1 gene region was detected in three, NDM-1+OXA-48 gene region was detected in two, 0XA-48 was detected in eight, and KPC gene region was detected in nine isolates. VIM and IMP-1 gene regions were not detected. Ceftolozane-tazobactam resistance was detected in seven isolates, whereas CZA resistance was not detected among the eight $K$. pneumoniae isolates producing only $0 X A-48$. NDM-1 and OXA-48 co-producing isolates were detected resistant to C/T and CZA with high minimum inhibitory concentration (MIC) levels (MIC $\geq 256 \mu \mathrm{g} /$ $\mathrm{ml}$ ). All NDM-1 producing isolates had high MIC levels (MIC $\geq 256 \mu \mathrm{g} / \mathrm{ml}$ ) to both $\mathrm{C} / \mathrm{T}$ and CZA. Ceftazidime-avibactam resistance was detected in only one isolate, whereas $\mathrm{C} / \mathrm{T}$ resistance was detected in all $K$. pneumoniae isolates producing KPC. Ceftolozane-tazobactam was detected inefficient whereas CZA was found very efficient in MDR K. pneumoniae isolates producing KPC.

Conclusion: According to the obtained data, we detected the in vitro antibacterial activity of CZA against the MDR $K$. pneumoniae isolates was superior to that of C/T. Ceftolozane-tazobactam was found to be weakly efficient, whereas CZA was found to be highly efficient against the MDR K. pneumoniae isolates producing OXA-48 and KPC. Because avibactam can inhibit the activity of KPC-type carbapenemase, the combination drug CZA should be considered to be effective in the treatment of KPC-type carbapenemase-producing strains but noneffective against NDM-type carbapenemase-producing strains.

Keywords: Klebsiella pneumoniae, multi-drug resistant, ceftazidime-avibactam, ceftolozane-tazobactam, carbapenemase enzymes

Cite this article as: : Terzi HA, Aydemir Ö, Demiray T, Köroğlu M, Altındiş M. Evaluation of In Vitro Activity of Ceftolozane-tazobactam and Ceftazidime-avibactam Against Carbapenemase-producing Multi-drug Resistant Klebsiella pneumoniae Isolates. Mediterr J Infect Microb Antimicrob. 2020;9:11. 
Giriş: Çalışmamızda seftazidim-avibaktam (CZA) ve seftolozan-tazobaktamın (C/T) çoklu ilaca dirençli (ÇiD) Klebsiella pneumoniae izolatlarındaki in vitro etkinliklerinin incelenmesi amaçlanmıştır. Ayrıca karbapenem direncinden sorumlu tutulan karbapenemaz enzim tiplerinin belirlenerek, bu enzimlere göre CZA ve C/T etkinliğinin karşılaştırılması amaçlanmıştır.

Gereç ve Yöntem: İncelenen 22 çiD K. pneumoniae izolatının tanımlama ve antibiyotik duyarlılık çalışmaları VITEK $2^{\oplus}$ (BioMérieux, Fransa) otomatize sistemi kullanılarak yapılmıştır. Seftolozan-tazobaktam ve CZA etkinliği gradiyent strip test (Liofilchem MIC strip test, İtalya) ile tespit edilmiştir. Karbapenemaz enzimi kodlayan bla $I_{I M P-1}, b / a_{K P C^{\prime}} b / a_{N D M-1} b / a_{O X A-48}$ ve $b / a_{V I M}$ gen bölgeleri Xpert CARBA-R test kitleri (Cepheid, Sunnyvale, CA, USA) kullanılarak araştırılmıştır.

Bulgular: CZA direnci; altı (\%27) izolatta görülürken, C/T direnci; 21 (\%95) izolatta tespit edilmiştir. Moleküler yöntemle 22 K. pneumoniae izolatının üçünde NDM-1, ikisinde NDM-1+OXA-48, sekizinde OXA-48 ve dokuzunda KPC geni tespit edilmiştir. VIM ve IMP-1 gen bölgeleri hiçbir izolatta saptanmamıştır. Sadece OXA-48 üreten sekiz K. pneumoniae izolatı arasında; yedi izolat C/T'ye karşı dirençli iken, CZA tüm izolatlarda duyarlı bulunmuştur. OXA-48 üretiminin yanında NDM-1 üretimi de saptanan izolatlarda ise C/T ve CZA'ya karşı yüksek minimum inhibitör konsantrasyon (MiK) düzeylerinde direnç (MiK $\geq 256 \mu \mathrm{g} / \mathrm{ml}$ ) saptanmıştır. NDM-1 üretimi saptanan izolatların tümünde C/T ve CZA'nın her ikisine yüksek MiK düzeylerinde direnç (MiK > $256 \mu \mathrm{g} / \mathrm{ml}$ ) saptanmıştır. KPC üreten $K$. pneumoniae izolatlarının tümü C/T'ye dirençli tespit edilirken, CZA'ya karşı sadece bir izolatta direnç saptanmıştır. KPC üreten ÇiD K. pneumoniae izolatlarında CZA çok etkili bulunurken, C/T'nin etkili olmadığı tespit edilmiştir.

Sonuç: Çalışmamızdaki çiD K. pneumoniae izolatlarında CZA'nın in vitro antibakteriyel etkinliği, C/T'den daha fazla bulunmuştur. OXA-48 ve KPC üreten ÇID K. pneumoniae izolatlarında CZA çok etkili bulunurken, C/T'nin etkinliğinin düşük olduğu tespit edilmiştir. Avibaktamın KPC tipi karbapenemazları inhibe edebilmesi, CZA kombinasyonunun KPC tipi karbapenemaz üreten izolatlarda etkili bir seçenek olacağını düşündürmektedir. Ancak NDM tipi karbapenemaz üreten izolatlarda, CZA'nın etkinliğinin olmadığı görülmüştür.

Anahtar Kelimeler: Klebsiella pneumoniae, çoklu ilaca dirençli, seftazidim-avibaktam, seftolozan-tazobaktam, karbapenemaz enzimleri

\section{Introduction}

Antibiotic resistance encountered in Gram-negative bacteria, especially the Enterobacteriaceae family and non-fermentative bacteria, has led to a decrease in antibiotic options used in the treatment of infections caused by these bacteria, thus increasing the morbidity and mortality rates ${ }^{[1,2]}$. The production of extended spectrum beta-lactamase (ESBL) is common in Gram-negative bacteria. In recent years, the production of carbapenemase has also increased, leading to multi-drug resistance (MDR) ${ }^{[3]}$.

In the last 20 years, the number of newly developed and used antibiotics has been decreasing. For this reason, some antibiotics are used in combination nowadays to benefit from their synergistic effects. Ceftolozane, a new third generation cephalosporin, has been put into use in combination with the beta-lactamase inhibitor tazobactam. This antibiotic has been found effective against most Gram-negative bacteria, including the Enterobacteriaceae family. Ceftolozane-tazobactam (C/T) (Zerbaxa; Merck \& Co., Kenilworth, NJ, USA) was approved for use in complicated intraabdominal infections and complicated urinary tract infections including pyelonephritis in 2014 $4^{[1,4]}$. Ceftazidime-avibactam (CZA) (Avycaz; Allergen, Inc., Irvine, CA, USA) is another third-generation cephalosporin and betalactamase inhibitor combination that was approved for use in the same infections as $C / T$ in $2015^{[1,4]}$. Ceftazidime-avibactam has the same spectrum of activity as ceftazidime against Enterobacteriaceae. However, the addition of avibactam extended its activity against resistant strains carrying certain beta-lactamases ${ }^{[1]}$. Ceftolozane, a new oxyimino-aminothiazolyl cephalosporin with a structure similar to ceftazidime, is less sensitive to hydrolysis with AmpC in contrast to ceftazidime and is also less affected by porin loss than ceftazidime. Tazobactam and avibactam inhibit serine beta lactamase. In addition to inhibiting ESBL, avibactam also effectively inhibits Class A carbapenemases such as AmpC beta-lactamases and $\mathrm{KPC}^{[5,6]}$. However, it has no activity against metallo beta-lactamases ${ }^{[3]}$.

There are few studies investigating the effectiveness of CZA and $\mathrm{C} / \mathrm{T}$ in MDR Klebsiella pneumoniae isolates and comparing their efficacy in these bacteria ${ }^{[7,8]}$. In our study, it was aimed to investigate the in vitro efficiency of CZA and C/T in MDR Klebsiella pneumoniae isolates. In addition, it was aimed to determine the types of carbapenemase enzymes that cause carbapenem resistance and to compare the efficiency of CZA and $\mathrm{C} / \mathrm{T}$ according to these enzymes.

\section{Materials and Methods}

\section{Bacterial Isolates and Antibiotic Susceptibility Tests}

Approval for this study was obtained from Sakarya University Faculty of Medicine Ethics Committee (ethics committee approval no: $71522473 / 050.0104 / 75$, date: 16.08 .2017$)$. Within the scope of this study, identification and antibiotic susceptibility tests of $22 \mathrm{MDR} K$ K. pneumoniae isolates isolated from various clinical specimens were performed in our laboratory. Susceptibilities of amikacin, gentamicin, ciprofloxacin, levofloxacin, cefepime, ceftriaxone, ceftazidime, piperacillin-tazobactam, cefuroximeaxetil, amoxicillin-clavulanate, imipenem, meropenem and 
trimethoprim-sulfamethoxazole were studied with VITEK 2 (BioMérieux, Fransa) automated system.

In K. pneumoniae isolates included in the study; strains found resistant to three or more of antimicrobial agents including piperacillin-tazobactam, cefepime, meropenem, ciprofloxacin, and aminoglycosides, were considered $\mathrm{MDR}^{[9]}$.

\section{Minimum Inhibitor Concentration (MIC) Tests}

The $\mathrm{C} / \mathrm{T}$ and $\mathrm{CZA}$ activities were determined by the gradient strip test (Liofilchem MIC strip test, Italy). Antimicrobial susceptibility results were evaluated according to the CLSI 2018 criteria ${ }^{[10]}$. For $\mathrm{CZA}_{\text {; }} \mathrm{MIC} \leq 8 \mu \mathrm{g} / \mathrm{ml}$ is considered susceptible and $\geq 16 \mu \mathrm{g} /$ $\mathrm{ml}$ is considered resistant. For $\mathrm{C} / \mathrm{T} ; \mathrm{MIC} \leq 2 \mu \mathrm{g} / \mathrm{ml}$ is considered susceptible, $\mathrm{MIC}=4 \mu \mathrm{g} / \mathrm{ml}$ is considered medium sensitive, and MIC $\geq 8 \mu \mathrm{g} / \mathrm{ml}$ is considered resistant ${ }^{[11]}$.

Carbapenem resistance was confirmed by restudying gradient test strips (E-test, BioMérieux, France). Isolates that were ertapenem resistant $(\geq 2 \mu \mathrm{g} / \mathrm{ml})$ and/or meropenem resistant $(\geq 4$ $\mu \mathrm{g} / \mathrm{ml}$ ) were defined as carbapenem resistant according to MIC values.

\section{Modified Carbapenemase Inactivation Test (CIT)}

A loopful was taken from the isolate in which carbapenemase enzyme production would be investigated, suspended in sterile distilled water and $10 \mu \mathrm{l}$ Meropenem disc (BioMérieux, France) was thrown into it. After two hours of incubation, the Meropenem disc from the suspension was placed on E. coli ATCC 29522 inoculated Mueller-Hinton (Merck, USA) agar medium and incubated at $35{ }^{\circ} \mathrm{C}$ for six hours. If growth occured around the meropenem disc (no inhibition zone) at the end of the sixhour period, the result of the test was considered positive ${ }^{[10]}$.

\section{Carbapenemase Nordmann-Poirel (Carba NP) test}

The Carba NP (BioMérieux, France) test was studied in accordance with the manufacturer's recommendations. The bacterial colony to be tested was suspended in lysis buffer and incubated for 30 minutes. This bacterial suspension was centrifuged at $10,000 \mathrm{x}$ $g$ for five minutes at room temperature. The solution prepared using the supernatant, imipenem monohydrate (Sigma, SaintQuentin Fallavier, France), phenol red and $0.1 \mathrm{mmol} / \mathrm{l} \mathrm{ZnSO}_{4}$ (Merck Millipore, Guyancourt, France) were mixed in 96-well plates. The phenol red solution mixture and the enzymatic suspension were incubated at $37^{\circ} \mathrm{C}$ for two hours. The test results were then interpreted.

\section{Molecular Tests}

The $b / a_{I M P-1^{\prime}} b / a_{K P C^{\prime}} b / a_{N D M-1^{\prime}} b / a_{O X A-48}$ and $b / a_{V I M}$ gene regions were investigated with Xpert CARBA-R Test kits (Cepheid, Sunnyvale, CA, USA) of the Gene-Xpert system in all Klebsiella isolates included in the study.
After the incubation of carbapenem-resistant isolates in blood agar medium at $35-37^{\circ} \mathrm{C}$ for 24 hours, the colonies from fresh colonies of these isolates were transferred to Xpert sample buffer with the help of a sterile swap. Two $\mathrm{ml}$ of this suspension was transferred to a commercial ready-to-use cartridge where DNA extraction, amplification and detection reactions would be performed. The cartridge was then loaded into the Gene-Xpert ${ }^{\circ}$ instrument and the results were evaluated according to the manufacturer's instructions within one hour.

\section{Results}

All of the MDR $K$. pneumoniae isolates included in the study were isolated from intensive care units. Twelve (55\%) of the clinical samples were included in the study as rectal swab, six $(27 \%)$ as blood sample, two (9\%) as wound sample and two $(9 \%)$ as urine samples. One of the isolates obtained from more than one clinical sample of the same patient was included in the study. All isolates were evaluated as positive for carbapenemase in the CIT and Carba NP tests which were carried out to detect Carbapenemase production. The clinical, molecular and antibiotic susceptibility test results of the analyzed MDR $K$. pneumoniae isolates are presented in Table 1.

It was determined that the $45 \%$ of MDR $K$. pneumoniae isolates included in the study were resistant to amikacin and 90\% were resistant to gentamicin. Ceftazidime-avibactam resistance was observed in six (27\%) isolates, while $\mathrm{C} / \mathrm{T}$ resistance was detected in $21(95 \%)$ isolates. All isolates resistant to CZA were also found to be resistant to $\mathrm{C} / \mathrm{T}$.

While 12 (55\%) of the C/T-resistant MDR K. pneumoniae isolates were isolated from rectal swab, six $(27 \%)$ from blood sample, two (9\%) from wound sample and one (5\%) from urine sample; three (14\%) of CZA-resistant $K$. pneumoniae isolates were isolated from blood sample, two (9\%) from rectal swab, and one (5\%) from urine sample.

In our study, five gene regions encoding carbapenemase were investigated in 22 carbapenem resistant $K$. pneumoniae isolates by molecular method. As a result of this investigation, three of these isolates had NDM-1, two had NDM-1/OXA-48, eight had OXA-48 and nine had KPC gene regions. VIM and IMP-1 gene regions were not detected in any isolate.

Among the eight $K$. pneumoniae isolates producing only OXA48 , seven isolates were resistant to C/T (MIC: $12-256 \mu \mathrm{g} / \mathrm{ml}$ ), while all isolates were susceptible to CZA (MIC: $0.5-1.5 \mu \mathrm{g} / \mathrm{ml}$ ). A high level of resistance to $\mathrm{C} / \mathrm{T}$ and $\mathrm{CZA}$ (MIC $>=256 \mu \mathrm{g} / \mathrm{ml}$ ) was detected in isolates with $0 \mathrm{XA}-48$ as well as NDM-1 production. While CZA was found to be very effective in MDR K. pneumoniae isolates producing OXA-48, C/T was found to be less effective in these isolates. 
A high level of resistance (MIC $>256 \mu \mathrm{g} / \mathrm{ml}$ ) was detected both against $\mathrm{C} / \mathrm{T}$ and $\mathrm{CZA}$ in all isolates with NDM-1 production. While all KPC-producing $K$. pneumoniae isolates were found resistant to C/T (MIC: $32-256 \mu \mathrm{g} / \mathrm{ml}$ ), resistance to CZA was detected in only one isolate (MIC: $16 \mu \mathrm{g} / \mathrm{ml}$ ). While CZA was very effective (MIC: $0.20-3 \mu \mathrm{g} / \mathrm{ml}$ ) in MDR K. pneumoniae isolates producing $\mathrm{KPC}$, it was determined that $\mathrm{C} / \mathrm{T}$ was not effective in these isolates.

\section{Discussion}

Today, treatment options remain limited in infections caused by resistant Gram-negative bacteria. However, there are various treatment algorithms recommended according to the source of infection in the treatment of carbapenem-resistant Enterobacteriaceae. It has been reported that combination therapy can reduce mortality in carbapenem-resistant Enterobacteriaceae infections compared with monotherapy ${ }^{[12-14]}$. Options such as aminoglycoside, tigecycline, fosfomycin, and rifampin can be added in addition to meropenem or doripenem as combined treatment options ${ }^{[15]}$.
The benefits of combination therapy include prevention of inappropriate antibiotic use, potential synergistic effects, and suppression of resistance development ${ }^{[14]}$. Since all monotherapy options have significant limitations (pharmacokinetics, toxicity, resistance development), optimization of therapy with combined antibiotics may be an important option. However, with combination therapy, an increased risk of Clostridium difficile infection, the likelihood of colonization or infection with other resistant bacteria or side effects such as nephrotoxicity may be observed $^{[14,16]}$

It has been reported in various publications that the efficiency of $\mathrm{C} / \mathrm{T}$ and $\mathrm{CZA}$ in infections caused by resistant isolates is higher than other cephalosporins and beta lactamase inhibitors ${ }^{[17,18]}$. In studies conducted with carbapenem-resistant Enterobacteriaceae isolates, C/T susceptibility was detected between 10-97.3\% and CZA susceptibility between 45\% and $100 \%{ }^{[8,19-29]}$. The $\mathrm{C} / \mathrm{T}$ and CZA resistance rates we examined in our study were determined as $95.4 \%$ and $27.2 \%$, respectively, in MDR K. pneumoniae isolates. In addition, CZA and C/T were found to be the most effective drugs in the beta-lactam group,

\begin{tabular}{|c|c|c|c|c|c|}
\hline \multirow[t]{2}{*}{ Strain no } & \multirow[t]{2}{*}{ Sample } & \multirow[t]{2}{*}{ Intensive care unit } & \multicolumn{2}{|c|}{$\mathrm{MIC}(\mu \mathrm{g} / \mathrm{ml})$} & \multirow[t]{2}{*}{ Gene-Xpert ${ }^{\circledR}$} \\
\hline & & & CZA & $\mathrm{C} / \mathrm{T}$ & \\
\hline 1 & Blood & Anesthesiology & 0.75 & 256 & OXA-48 \\
\hline 2 & Urine & Surgery & 0.5 & 4 & OXA-48 \\
\hline 3 & Blood & Anesthesiology & 1.5 & 256 & OXA-48 \\
\hline 4 & Wound & Surgery & 0.75 & 256 & OXA-48 \\
\hline 5 & Wound & Infectious diseases & 1 & 16 & OXA-48 \\
\hline 6 & Blood & Anesthesiology & 0.75 & 256 & OXA-48 \\
\hline 7 & Rectal swab & Anesthesiology & 0.75 & 12 & OXA-48 \\
\hline 8 & Rectal swab & Anesthesiology & 0.75 & 12 & OXA-48 \\
\hline 9 & Blood & Anesthesiology & $>=256$ & $>=256$ & NDM-1+0XA-48 \\
\hline 10 & Rectal swab & Anesthesiology & $>=256$ & $>=256$ & NDM-1+OXA-48 \\
\hline 11 & Blood & Anesthesiology & $>=256$ & $>=256$ & NDM-1 \\
\hline 12 & Blood & Anesthesiology & $>=256$ & $>=256$ & NDM-1 \\
\hline 13 & Urine & Internal medicine & $>=256$ & $>=256$ & NDM-1 \\
\hline 14 & Rectal swab & Anesthesiology & 3 & 256 & KPC \\
\hline 15 & Rectal swab & Anesthesiology & 0.75 & 256 & KPC \\
\hline 16 & Rectal swab & Anesthesiology & 0.20 & 256 & KPC \\
\hline 17 & Rectal swab & Anesthesiology & 0.75 & 256 & KPC \\
\hline 18 & Rectal swab & Anesthesiology & 0.12 & 32 & KPC \\
\hline 19 & Rectal swab & Anesthesiology & 0.12 & 256 & KPC \\
\hline 20 & Rectal swab & Anesthesiology & 0.64 & 256 & $\mathrm{KPC}$ \\
\hline 21 & Rectal swab & Anesthesiology & 0.3 & 64 & KPC \\
\hline 22 & Rectal swab & Anesthesiology & 16 & 256 & KPC \\
\hline
\end{tabular}

MIC: Minimum inhibitory concentration, CZA: Ceftazidime-avibactam, C/T: Ceftolozane-tazobactam 
and were found more effective than most antibiotics, including carbapenems and fluoroquinolones.

To date, few studies have been conducted comparing the efficiency of $\mathrm{C} / \mathrm{T}$ and $\mathrm{CZA}$ in resistant Gram-negative bacteria ${ }^{[7,8]}$. In a study conducted with carbapenem-resistant Enterobacteriaceae isolates, CZA was found to be more effective than $\mathrm{C} / \mathrm{T}$ (susceptibility $45 \%$ and $10 \%$, respectively) ${ }^{[8]}$. The reason for this was shown to be the change in susceptibility according to different carbapenemase types they detected. In various studies performed with carbapenemase-producing Enterobacteriaceae isolates, it has been reported that CZA and C/T susceptibilities may vary according to the carbapenemase enzyme type ${ }^{[5,7,8]}$. In the study of Evans et al. ${ }^{[30]}$, CZA and C/T susceptibilities were reported as $100 \%$ in carbapenem susceptible strains. However, in the same study, CZA and C/T susceptibility rates were reported as $0 \%$ in carbapenem-resistant strains producing VIM, 50\% in KPC-producing strains, and $73.1 \%$ in all strains for C/T and $77.2 \%$ in all strains for CZA. In the study of Alatoom et al. ${ }^{\left[{ }^{[8]}\right.}$, isolates were divided into three groups according to carbapenemase enzyme types. While CZA showed high activity (80\%) in the group with OXA-48 positive isolates, it was found to show low activity in isolates in the other two groups containing NDM and NDM+OXA (29\% and 5\%, respectively). On the other hand, $\mathrm{C} / \mathrm{T}$ was evaluated as weakly effective $(13 \%, 21 \%$ and $0 \%$, respectively) in all three groups. They showed the high number of NDM and NDM+OXA positive isolates (55\%) in their study as the reason for the lower CZA susceptibility rates compared to other studies (Table 2).

In our study, the efficiency of CZA in MDR K. pneumoniae isolates was found to be higher than C/T (27.2\% vs. 95.4\% resistance, respectively). We thought that this change in susceptibility rates was due to the fact that all isolates in our study were MDR and the production of carbapenemase we detected in all of them. In addition, variation in carbapenemase-producing genes or differences in resistance mechanisms to both drugs may also have affected this result ${ }^{[31]}$. Ceftazidime-avibactam has also been reported to be effective in the treatment of KPC-type carbapemenase-producing isolates, especially since avibactam can inhibit KPC type carbapemenase activity ${ }^{[8]}$. In our study, in accordance with the literature, while CZA was found to be very effective in MDR $K$. pneumoniae isolates producing KPC, it was determined that $\mathrm{C} / \mathrm{T}$ was not effective in these isolates. Similarly, while CZA was found to be very effective in MDR $K$. pneumoniae isolates producing OXA-48, it was determined that the efficiency of $\mathrm{C} / \mathrm{T}$ in these isolates was low. In the NDM1 producing MDR $K$. pneumoniae isolates, a high value of resistance ( $\mathrm{MIC}>=256 \mu \mathrm{g} / \mathrm{ml}$ ) was found against both $\mathrm{C} / \mathrm{T}$ and CZA.

The fact that $\mathrm{C} / \mathrm{T}$ and $\mathrm{CZA}$ activities can change according to carbapenemase production reveals the importance of detecting carbapenemase resistance genes. In the study of Wang et al. ${ }^{[32]}$, $\mathrm{CZA}_{\mathrm{MIC}}$ values in $E$. cloacae and $K$. pneumoniae isolates

Table 2. The ceftolozane-tazobactam and ceftazidime-avibactam susceptibility rates in studies with resistant Enterobacteriaceae isolates

\begin{tabular}{|c|c|c|c|c|c|c|}
\hline Country & Authors & Publication date & Resistance profile & Number & $\mathrm{C} / \mathrm{T}(\%)$ & CZA (\%) \\
\hline Spain & Tato et al. ${ }^{[19]}$ & 2015 & ESBL (+) & 66 & 77.2 & - \\
\hline UK & Livermore et al. ${ }^{[20]}$ & 2017 & ESBL (+) & 1048 & 32.3 & - \\
\hline Europe & Pfaller et al. ${ }^{[21]}$ & 2017 & ESBL (+) & 906 & 82.8 & - \\
\hline USA & Hirsch et al. ${ }^{[22]}$ & 2017 & ESBL (+) & 74 & 97.3 & 100 \\
\hline UAE & Alatoom et al. ${ }^{[8]}$ & 2017 & Carbapenem resistant & 60 & 10 & 45 \\
\hline UAE & Alatoom et al. ${ }^{[8]}$ & 2017 & ESBL (+) & 29 & 97 & 100 \\
\hline Germany & Seifert et al. ${ }^{[23]}$ & 2018 & ESBL (+) & 83 & 67.4 & - \\
\hline Taiwan & Jean et al. ${ }^{[24]}$ & 2018 & ESBL (+) & 1359 & 89.1 & 99.4 \\
\hline USA & Shields et al. ${ }^{[25]}$ & 2018 & Carbapenem resistant & 74 & - & 81 \\
\hline USA & Van Horn et al. ${ }^{[26]}$ & 2018 & Carbapenem resistant & 245 & - & 98.3 \\
\hline USA & Van Horn et al. ${ }^{[26]}$ & 2018 & ESBL (+) & 28 & - & 100 \\
\hline USA & Shortridge et al. ${ }^{[27]}$ & 2018 & ESBL (+) & 1450 & 87.5 & - \\
\hline USA & Castanheira et al. ${ }^{[28]}$ & 2018 & ESBL (+) & 145 & 82.7 & - \\
\hline APAC & Pfaller et al. ${ }^{[29]}$ & 2018 & ESBL (+) & 378 & 79.1 & - \\
\hline Turkey & This study & - & MDR & 22 & 4.6 & 72.8 \\
\hline
\end{tabular}

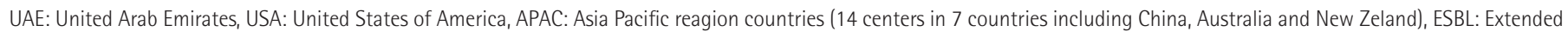
spectrum beta-lactamase, MDR: Multi-drug resistant, C/T: Ceftolozane-tazobactam, CZA: Ceftazidime-avibactam 
isolated in China between 2011 and 2012 were found to be 0.5 and $1 \mathrm{mg} / \mathrm{I}$, respectively. In the study of Yin et al. ${ }^{[7]}$ conducted in 2017, CZA MIC ${ }_{90}$ values in E. cloacae and K. pneumoniae were reported as $\geq 32$ and $4 \mathrm{mg} / \mathrm{l}$, respectively, and it was suggested that the decrease in CZA susceptibility rates in these species might be associated with the rapid increase in the spread of especially NDM-1 producing isolates in carbapenem-resistant Enterobacteriaceae.

One of the limitations of our study was the low number of isolates tested. In addition, the clinical sample diversity in the isolates was limited. In addition, another limitation of our study was that only MDR K. pneumoniae isolates were tested.

\section{Conlusion}

All of the MDR K. pneumoniae isolates examined in our study were found to be resistant to other beta lactam and beta lactamase inhibitors as well as to carbapenems. In vitro antibacterial activity of CZA against $K$. pneumoniae was found to be higher than $C / T$. While CZA was found to be very effective in OXA-48 and KPC producing MDR K. pneumoniae isolates, it was determined that the efficiency of $\mathrm{C} / \mathrm{T}$ was low. The ability of avibactam to inhibit KPC type carbapenemases suggests that the CZA combination will be an effective option in isolates producing KPC type carbapenemase. However, CZA was found to be ineffective in isolates producing NDM type carbapenemase in our study. More comprehensive studies are needed to determine the role of these two combined treatment options in the treatment of infections caused by MDR Gramnegative bacteria.

\section{Ethics}

Ethics Committee Approval: Approval was obtained from Sakarya University Faculty of Medicine Ethics Committee for this study (ethics committee approval no: 71522473/050.0104/75, date: 16.08.2017).

Informed Consent: Informed consent form was not received due to the retrospective nature of the study.

Peer-review: Externally and internally peer-reviewed.

\section{Authorship Contributions}

Surgical and Medical Practices: H.A.T., M.K., Concept: H.A.T., Ö.A., Design: H.A.T., Ö.A., Data Collection or Processing: H.A.T., M.K., Ö.A., Analysis or Interpretation: H.A.T., M.K., Literature Search: H.A.T., M.K., T.D., M.A., Ö.A., Writing: H.A.T., M.K., T.D., M.A., Ö.A.

Conflict of Interest: No conflict of interest was declared by the authors.

Financial Disclosure: The authors declared that this study received no financial support.

\section{References}

1. Goodlet KJ, Nicolau DP, Nailor MD. Ceftolozane/tazobactam and ceftazidime/avibactam for the treatment of complicated intra-abdominal infections. Ther Clin Risk Manag. 2016;12:1811-26.

2. Sader HS, Farrell DJ, Castanheira M, Flamm RK, Jones RN. Antimicrobial activity of ceftolozane/tazobactam tested against Pseudomonas aeruginosa and Enterobacteriaceae with various resistance patterns isolated in European hospitals (2011-12). J Antimicrob Chemother. 2014;69:2713-22.

3. Rodríguez-Núñez 0 , Ripa $M$, Morata $L$, de la Calle $C$, Cardozo $C$, Fehér $C$, Pellicé M, Valcárcel A, Puerta-Alcalde P, Marco F, García-Vidal C, Del Río A, Soriano A, Martínez-Martinez JA. Evaluation of ceftazidime/avibactam for serious infections due to multidrug-resistant and extensively drug-resistant Pseudomonas aeruginosa. J Glob Antimicrob Resist. 2018;15:136-9.

4. Liscio JL, Mahoney MV, Hirsch EB. Ceftolozane/tazobactam and ceftazidime/ avibactam: two novel beta-lactam/beta-lactamase inhibitor combination agents for the treatment of resistant Gram-negative bacterial infections. Int J Antimicrob Agents. 2015;46:266-71

5. Humphries RM, Hindler JA, Wong-Beringer A, Miller SA. Activity of Ceftolozane-Tazobactam and Ceftazidime-Avibactam against BetaLactam-Resistant Pseudomonas aeruginosa Isolates. Antimicrob Agents Chemother. 2017;61:e01858-17.

6. van Duin D, Bonomo RA. Ceftazidime/Avibactam and Ceftolozane/ Tazobactam: Second-generation $\beta$-Lactam/ $\beta$-Lactamase Inhibitor Combinations. Clin Infect Dis. 2016;63:234-41.

7. Yin D, Wu S, Yang Y, Shi Q, Dong D, Zhu D, Hu F, China Antimicrobial Surveillance Network (CHINET) Study Group. Results from the China Antimicrobial Surveillance Network (CHINET) in 2017 of the In Vitro Activities of Ceftazidime-Avibactam and Ceftolozane-Tazobactam against Clinical Isolates of Enterobacteriaceae and Pseudomonas aeruginosa. Antimicrob Agents Chemother. 2019;63:e02431-18.

8. Alatoom A, Elsayed H, Lawlor K, AbdelWareth L, El-Lababidi R, Cardona L, Mooty M, Bonilla MF, Nusair A, Mirza I. Comparison of antimicrobial activity between ceftolozane-tazobactam and ceftazidime-avibactam against multidrug-resistant isolates of Escherichia coli, Klebsiella pneumoniae, and Pseudomonas aeruginosa. Int J Infect Dis. 2017:62:39-43.

9. Magiorakos AP, Srinivasan A, Carey RB, Carmeli $Y$, Falagas ME, Giske CG, Harbarth S, Hindler JF, Kahlmeter G, Olsson-Liljequist B, Paterson DL, Rice LB, Stelling J, Struelens MJ, Vatopoulos A, Weber JT, Monnet DL. Multidrugresistant, extensively drug-resistant and pandrug-resistant bacteria: an international expert proposal for interim standard definitions for acquired resistance. Clin Microbiol Infect. 2012;18:268-81.

10. Wayne P. Performance standards for antimicrobial susceptibility testing, $11^{\text {th }}$ ed. CLSI supplement M100. Clinical and Laboratory Standards Institute; 2018.

11. EUCAST. Breakpoint tables for interpretation of MICs and zone diameters. EUCAST document version 6.0. European Committee on Antimicrobial Susceptibility Testing, 2016. Available from: https://www.eucast.org/ fileadmin/src/media/PDFs/EUCAST_files/Breakpoint_tables/v_6.0_ Breakpoint_table.pdf

12. Qureshi ZA, Paterson DL, Potoski BA, Kilayko MC, Sandovsky G, Sordillo E, Polsky B, Adams-Haduch JM, Doi Y. Treatment outcome of bacteremia due to KPC-producing Klebsiella pneumoniae: superiority of combination antimicrobial regimens. Antimicrob Agents Chemother. 2012;56:2108-13.

13. Tumbarello $M$, Viale $P$, Viscoli $C$, Trecarichi EM, Tumietto $F$, Marchese $A$ Spanu T, Ambretti S, Ginocchio F, Cristini F, Losito AR, Tedeschi S, Cauda $R$, Bassetti M. Predictors of mortality in bloodstream infections caused by Klebsiella pneumoniae carbapenemase producing $K$. pneumoniae: importance of combination therapy. Clin Infect Dis. 2012;55:943-50. 
14. Petrosillo N, Giannella M, Lewis R, Viale P. Treatment of carbapenemresistant Klebsiella pneumoniae: the state of the art. Expert Rev Anti Infect Ther. 2013;11:159-77.

15. Morrill HJ, Pogue JM, Kaye KS, LaPlante KL. Treatment Options for Carbapenem-Resistant Enterobacteriaceae Infections. Open Forum Infect Dis. 2015;2:ofv050.

16. Paul M, Carmeli $Y$, Durante-Mangoni $E$, Mouton JW, Tacconelli $E$, Theuretzbacher U, Mussini C, Leibovici L. Combination therapy for carbapenem-resistant Gram-negative bacteria. J Antimicrob Chemother. 2014;69:2305-9.

17. Sader HS, Castanheira M, Shortridge D, Mendes RE, Flamm RK. Antimicrobial Activity of Ceftazidime-Avibactam Tested against Multidrug-Resistant Enterobacteriaceae and Pseudomonas aeruginosa Isolates from U.S. Medical Centers, 2013 to 2016. Antimicrob Agents Chemother. 2017;61:e01045-17.

18. Shortridge D, Pfaller MA, Castanheira M, Flamm RK. Antimicrobial activity of ceftolozane-tazobactam tested against Enterobacteriaceae and Pseudomonas aeruginosa collected from patients with bloodstream infections isolated in United States hospitals (2013-2015) as part of the Program to Assess Ceftolozane-Tazobactam Susceptibility (PACTS) surveillance program. Diagn Microbiol Infect Dis. 2018;92:158-63.

19. Tato $M$, Garcia-Castillo $M$, Bofarull AM, Canton R, CENIT Study Group. In vitro activity of ceftolozane/tazobactam against clinical isolates of Pseudomonas aeruginosa and Enterobacteriaceae recovered in Spanish medical centres: results of the CENIT study. Int J Antimicrob Agents. 2015;46:502-10.

20. Livermore DM, Mushtaq S, Meunier D, Hopkins KL, Hill R, Adkin R, Chaudhry A, Pike R, Staves P, Woodford N; BSAC Resistance Surveillance Standing Committee. Activity of ceftolozane/tazobactam against surveillance and 'problem' Enterobacteriaceae, Pseudomonas aeruginosa and nonfermenters from the British Isles. J Antimicrob Chemother. 2017;72:227889.

21. Pfaller MA, Bassetti M, Duncan LR, Castanheira M. Ceftolozane/tazobactam activity against drug-resistant Enterobacteriaceae and Pseudomonas aeruginosa causing urinary tract and intraabdominal infections in Europe: report from an antimicrobial surveillance programme (2012-15). J Antimicrob Chemother. 2017;72:1386-95.

22. Hirsch EB, Zucchi $P$, Cheung N, Krevolin K, Emery C, Bias T. Activity of Ceftolozane/tazobactam (C/T) and Ceftazidime/avibactam (CZA) against Extended-spectrum Beta-lactamase (ESBL)-producing Enterobacteriaceae and Multidrug-resistant (MDR) Pseudomonas aeruginosa Isolates. IDWeek press conferences. 2017;P:1231.

23. Seifert H, Körber-Irrgang B, Kresken M; German Ceftolozane/Tazobactam Study Group. In-vitro activity of ceftolozane/tazobactam against Pseudomonas aeruginosa and Enterobacteriaceae isolates recovered from hospitalized patients in Germany. Int J Antimicrob Agents. 2018;51:227-34.

24. Jean SS, Lu MC, Shi ZY, Tseng SH, Wu TS, Lu PL, Shao PL, Ko WC, Wang FD, Hsueh PR. In vitro activity of ceftazidime-avibactam, ceftolozanetazobactam, and other comparable agents against clinically important
Gram-negative bacilli: results from the 2017 Surveillance of Multicenter Antimicrobial Resistance in Taiwan (SMART). Infect Drug Resist. 2018;11:1983-92.

25. Shields RK, Clancy CJ, Pasculle AW, Press EG, Haidar G, Hao B, Chen L, Kreiswirth BN, Nguyen MH. Verification of Ceftazidime-Avibactam and Ceftolozane-Tazobactam Susceptibility Testing Methods against Carbapenem-Resistant Enterobacteriaceae and Pseudomonas aeruginosa. J Clin Microbiol. 2018;56:e1093-17.

26. Van Horn KG, Sneed D, Goldstein EJC. Comparative "real world" in vitro activity of two new antimicrobials (ceftolozane-tazobactam and ceftazidime-avibactam) against ceftazidime non-susceptible Pseudomonas aeruginosa and resistant Enterobacteriaceae from california long term acute care hospitals. Clin Microbiol Infect Dis. 2018;3:1-4.

27. Shortridge D, Pfaller MA, Castanheira M, Flamm RK. Antimicrobial Activity of Ceftolozane-Tazobactam Tested Against Enterobacteriaceae and Pseudomonas aeruginosa with Various Resistance Patterns Isolated in U.S. Hospitals (2013-2016) as Part of the Surveillance Program: Program to Assess Ceftolozane-Tazobactam Susceptibility. Microb Drug Resist. 2018;24:563-77.

28. Castanheira M, Duncan LR, Mendes RE, Sader HS, Shortridge D. Activity of Ceftolozane-Tazobactam against Pseudomonas aeruginosa and Enterobacteriaceae Isolates Collected from Respiratory Tract Specimens of Hospitalized Patients in the United States during 2013 to 2015. Antimicrob Agents Chemother. 2018;62:e02125-17.

29. Pfaller MA, Shortridge D, Sader HS, Castanheira M, Flamm RK. Ceftolozane/ tazobactam activity against drug-resistant Enterobacteriaceae and Pseudomonas aeruginosa causing healthcare-associated infections in the Asia-Pacific region (minus China, Australia and New Zealand): report from an Antimicrobial Surveillance Programme (2013-2015). Int J Antimicrob Agents. 2018;51:181-9.

30. Evans SR, Tran TT, Hujer AM, Hill CB, Hujer KM, Mediavilla JR, Manca C, Domitrovic TN, Perez F, Farmer M, Pitzer KM, Wilson BM, Kreiswirth BN, Patel $R$, Jacobs MR, Chen L, Fowler VG Jr, Chambers HF, Bonomo RA, Antibacterial Resistance Leadership Group (ARLG). Rapid Molecular Diagnostics to Inform Empiric Use of Ceftazidime/Avibactam and Ceftolozane/Tazobactam against Pseudomonas aeruginosa: PRIMERS IV. Clin Infect Dis. 2019;68:1823-30.

31. Demiray T, Aydemir Ö, Kilic U, Yilmaz K, Koroglu M, Altindis M. Karbapenem Dirençli Klebsiella pneumoniae İzolatlarında Karbapenemaz Saptanmasında Karbapenemaz İnaktivasyon Testinin Kullanımı. Türk Mikrobiyol Cem Derg. 2017;47:78-82.

32. Wang $X$, Zhang $F$, Zhao $C$, Wang $Z$, Nichols WW, Testa $R$, Li H, Chen $H$, He W, Wang Q, Wang H. In Vitro Activities of Ceftazidime-Avibactam and Aztreonam-Avibactam against 372 Gram-Negative Bacilli Collected in 2011 and 2012 from 11 Teaching Hospitals in China. Antimicrob Agents Chemother. 2014;58:1774-8. 